\title{
Narrativas que acompanham a possessão dionisíaca na tragédia As bacantes, de Eurípides ${ }^{1}$
}

Orlando Luiz de Araújo²

http://lattes.cnpq.br/2680403686223727

Pedro Leno de Jesús da Silva 3

http://lattes.cnpq.br/2863027751340075

Recebido em 24/09/2018

Aceito em 11/01/2019

Resumo: Este artigo discutirá, a partir da tragédia grega de Eurípides, As Bacantes, a relação que se estabelece, entre o humano e o divino, focalizando, especiifcamente, a noção de loucura humana, quando se coloca face ao divino. Assim, o intuito é buscar, a partir de narrativas feitas por personagens, compreender o papel dessas narrativas incorporadas às ações dramatizadas e sua relação com a loucura das bacantes tebanas, bem como a loucura que aflige Penteu, comparando-as com o comportamento do coro das bacantes lídias. Além disso, a pesquisa enfoca a relação do comportamento insano com os elementos rituais que constituem a religião dionisíaca apresentada na peça, além de destacar a própria figura de Dioniso, uma vez que a loucura as põe em situação de estranhamento com valores opostos entre si, como a noção de civilidade e selvageria, humanidade e divindade. Como suporte teórico, para balizar a pesquisa, utilizamos categorias da Narratologia que nos permitem melhor entender como essas se produzem, no drama euripidiano, e qual a natureza da loucura.

Palavras-chave: Eurípides; Narratologia; Loucura; Divino; Humano.

Absctract: This article will discuss, starting from the Greek tragedy of Euripides, The Bacchae, the relation that is established between the human and the divine, focusing, specifically, the notion of human madness, when it stands before the divine. Thus, the intention is to seek, from narratives made by characters, to understand the role of these narratives incorporated to the dramatized actions and their relationship with the madness of the Theban women, as well as the madness that afflicts Penteu, comparing them with the behavior of the Chorus of the Lydian Bacchae. In addition, the research focuses on the relation of insane behavior to the ritual elements that constitute the Dionysian religion presented in the play, in addition to highlighting the very figure of Dionysus, since madness puts them in a situation of strangeness with opposing values, as the notion of civility and savagery, humanity and divinity. As a theoretical support, to mark the research, we use categories of Narratology that allow us to better understand how it is produced, in the Euripidean drama, and what is the nature of the madness.

Key-Words: Euripides; Narratology; Madness; Divine; Humain.

\section{INTRODUÇÃO}

\footnotetext{
${ }^{1}$ A presente pesquisa foi realizada com apoio financeiro da agência de fomento CAPES, a quem expressamos nossos agradecimentos.

2 Professor doutor no curso de Letras e no Programa de Pós-Graduação em Letras na Universidade Federal do Ceará (UFC). Email: orlando.araujo@ufc.br

3 Professor na Educação Básica e mestre pelo Programa de Pós-Graduação em Letras da Universidade Federal do Ceará (UFC). Email: pedrolenosilva@yahoo.com.br
} 
A tragédia As Bacantes, que foi encenada por volta de 405 a.C., é provavelmente uma das últimas peças de Eurípides e especula-se que foi produzida após a estada do seu autor no território da Macedônia, onde teria tido contato com organizações ritualísticas provenientes das antigas celebrações em honra ao deus Dioniso, das quais retirara elementos importantes para a caracterização do rito báquico e do comportamento das bacantes.

Neste trabalho pretendemos nos direcionar ao estudo do papel da loucura instaurada na cidade de Tebas com a chegada de Dioniso, compreender o papel das narrativas incorporadas às ações dramatizadas e sua relação com a loucura das bacantes tebanas, como também a loucura que aflige Penteu e nesse sentido, compará-las tanto com o comportamento do coro das bacantes lídias, quanto com a relação entre o comportamento insano e os elementos rituais que constituem a religião dionisíaca apresentada na peça, bem como com a própria figura de Dioniso, visto que a loucura põe as personagens em situação de estranhamento com valores opostos entre si: a noção de civilidade e selvageria, humanidade e divindade, o métron e a býbris. Constataremos a ação divina para a instauração da loucura no decorrer do enredo, à medida que analisamos os elementos narrativos associados a ações constituintes da tragédia e verificaremos as relações mantidas entre esses elementos e a menção ao comportamento das personagens afetadas pela possessão divina, influenciadas pela vontade do deus Dioniso, e qual o valor a associação de tais fenômenos atribui a essa obra. Desse modo, desenvolvemos este estudo pressupondo a loucura como a manifestação ou o meio mais conciso de uma divindade infligir castigo aos mortais que cometem uma býbris, sendo essa a maneira mais eficaz de anular as ações de um mortal e fazê-lo estagnar em seu ato, o que contraria os desejos divinos, tanto que, em $A s$ Bacantes, essa intervenção sempre parte de Dioniso, identificado como o deus da vinha, do vinho e do delírio místico.

O castigo tanto pode se manifestar no momento da libertação da loucura sofrida pela personagem, quando essa percebe as ações que praticou enquanto lhe faltava a razão, quanto a própria loucura pode ser entendida como castigo. O sofrimento e a humilhação se potencializam ao perceber que a vítima é também o praticante dos atos que o puseram na situação em que se encontra. Nesse ponto nos deparamos com o surgimento de elementos narrativos no enredo dramático, constitutivos de determinada estrutura do texto, passíveis de interpretação com base na relação entre drama, narrativa, loucura e interferência divina, ora para que se saiba o que se fez no momento de loucura, ora para que sejam recuperadas as informações acontecidas em um ambiente no qual a realidade humana se fragiliza, e as regras que a constituem são de outro plano, obedecendo à vontade dos deuses. Por isso, utilizaremos referências tanto à loucura e às ações praticadas pelos loucos, quanto à ação divina, praticada por Dioniso para nos guiarmos em nossa leitura.

\section{A CHEGADA DE DIONISO A TEBAS}

A tragédia inicia com a narrativa de Dioniso, que chega à terra em que fora outrora concebido, enquanto filho de uma mortal. Dioniso é tebano, ou sua parte mortal é de Tebas; enquanto divindade, é estrangeiro, vindo do Oriente para inserir seu culto naquele lugar, disfarçado de sacerdote de seu culto. Ele vislumbra um memorial em honra a sua mãe, junto ao palácio, que ainda queima em resultado ao evento que ali acontecera, referência ao mito

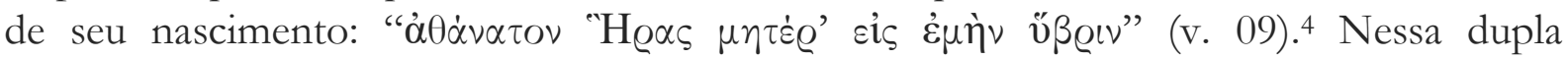

\footnotetext{
4 “Imortal violência de Hera à minha mãe" (Eu., Bacantes, v. 09, tradução nossa)
} 
apresentação, o tempo das ações se desloca entre presente e passado para que o prólogo tenha o seu papel no texto - contextualize o drama que ali se inicia e situe o espectador no tema de que o texto se vale - e para que o Dioniso euripidiano exponha sua história de seu próprio ponto de vista. Trata-se de uma tragédia em que identificamos a $\ddot{\beta} \beta$ ıs pela perspectiva divina.

O mito é o material do qual a tragédia se utiliza para construir seu próprio enredo, que pode recontá-lo sob a perspectiva do tragediógrafo, ou subvertê-lo, retirando ou inserindo ações da narrativa mítica no enredo trágico. Assim, o retorno ao mito do nascimento de Dioniso, que será narrado também pelo coro das bacantes lídias e por Penteu, e ainda citado por Cadmo e Tirésias ao longo do enredo, além de servir de ponto inicial para As Bacantes, é também o argumento que a sustenta. Como afirma Vernant (VERNANT, 2014, p. 336), "Dioniso não intervém, como fazem comumente os deuses na tragédia. Ele desempenha o papel principal".

Dioniso está ali, não só para instaurar os ritos dionisíacos na Hélade, como já o fizera em terras estrangeiras, mas também para impor castigo a sua família humana e a todos os que ultrajaram a imagem de sua mãe, afirmando não ter Sêmele engravidado de um deus, mas de um humano. As outras filhas de Cadmo afirmavam que Zeus castigara Sêmele por ter anunciado que a paternidade do filho que carregava em seu ventre era do pai dos deuses.

O motivo da escolha de Tebas como o lugar inicial de instauração do rito dionisíaco é exposto no posicionamento da família de Dioniso quanto a sua divindade. O castigo imposto às filhas de Cadmo é servirem involuntariamente a Dioniso, junto das outras mulheres tebanas, retiradas de casa loucas em frenesi. Dioniso já enlouquecera as mulheres tebanas e as atraíra para as montanhas, relato que se junta à narrativa de seu nascimento. Elas se comportam agora como mênades no monte Citéron, ambiência em que reina a vontade divina. Essa é a primeira referência à situação que serve de argumento a este trabalho. $\mathrm{O}$ espaço em que se confundem as vontades ou as ações humanas e divinas, estas sempre se sobrepondo àquelas, em que o mortal, sujeito aos desígnios dos deuses, nesse caso, Dioniso,

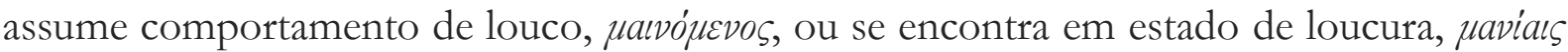
(v. 33), associado ao relato do próprio episódio. Como diz Dodds:

O que aconteceu no monte Citeron foi pura histeria, o pergisoso baquismo que desce como um castigo sobre os homens respeitáveis e os devasta contra suas vontades. [...] Resistir a Dioniso é reprimir o que há de elementar na nossa própria natureza, e o castigo é o repentino e completo colapso das represas internas, quando o elementar rompe a compulsão fazendo desaparecer a civilização. (DODDS, 2002, p. 274)

Em As Bacantes, são vários os fenômenos discursivos associados à presença do louco nas narrativas incorporadas ao enredo dramático. Primeiramente, o vocábulo grego $\mu a v i a$, segundo o dicionário Grego-Português/Português-Grego, de Isidro Pereira (PEREIRA,1990, p. 356), pode se referir ao estado de loucura, ao estado de fúria, ou ao estado em que se encontra quem celebra ritos a Dioniso. A divindade abrange o campo de influência daquilo que está além do que os valores da pólis permitem, para além, inclusive, do que a lucidez pode conceber.

Essa ambiência na qual impera a vontade divina sob a ação de um mortal, e a dionisíaca acima de qualquer outra, é mais compatível com a narração do que com a dramatização de tais atos. No caso de Dioniso, esse aspecto é ainda mais nítido. Por conta do espaço em que se pratica sua religião, esse mistério em torno da figura dionisíaca reflete-se na conjuntura de seu rito, agora praticado pelas tebanas, além das sacerdotisas lídias que vieram com 
Dioniso disfarçado e formaram o coro da tragédia. Por isso, sua primeira ação ao chegar à Tebas foi conduzi-las às montanhas, ambiente selvagem no qual não há normas sociais que atrapalhem suas transgressões. Aqui se mostra mais uma sutileza da figura dionisíaca: Dioniso age em Tebas, e lá está presente, mas está também nas montanhas, cultuado pelas mênades tebanas, conferindo-lhes força e poder inumanos.

Cria-se, então, no enredo da tragédia, uma polaridade de significados entre a civilização e a ordem ligadas à cidade, à moradia, à casa, sob liderança da força masculina de Penteu, e a selvageria e aparente desordem ligadas à montanha, à mata e aos perigos que ela encerra, lugar onde se cria o ambiente ritualístico habitado pelas bacantes, em que é interdita a presença masculina. Dioniso, entretanto, caminha facilmente por esses dois ambientes distintos: "Tudo se passa como se, durante todo o espetáculo, ao mesmo tempo que aparece no palco, ao lado das outras personagens do drama, Dioniso agisse num outro plano, nos bastidores, para atar o fio da intriga e maquinar seu desfecho.” (VERNANT, 2014, p. 336). Mas essa polaridade Dioniso pretende destruir, e, para fazê-lo, não obstante, esperará o ataque de Penteu a suas mênades.

Para Vernant (2014), a própria figura dionisíaca se divide de forma parecida com o enredo do drama de Eurípides. Em seu estudo sobre a máscara que representa o deus nas Bacantes, o historiador e antropólogo identifica, no desdobramento cênico de Dioniso, apresentado "como deus no theologeîon, e como estrangeiro lídio 'com ar de mulher' no palco" com a máscara trágica do ator, que tanto o proclama como o dissimula, uma "constante relação entre o Dioniso da religião cívica - o deus do culto oficial - e o Dioniso da representação trágica - o deus senhor da ilusão teatral" (VERNANT, 2014, p. 336). Sua narrativa no âmbito dramático é introspectiva, ele é narrador e narratário de seu relato, reconta para si como quem recapitula seus atos para prosseguir até sua meta; no âmbito teatral, seus narratários são os espectadores, os únicos a saberem naquele contexto o que está para acontecer, qual será o desfecho daquele enredo.

Ao buscarmos uma literatura que nos auxilie nessa análise, deparamo-nos com a obra de Irene de Jong (2014), que se posiciona junto dos narratologistas que consideram narrativos os textos cujos eventos são mediados por uma figura do narrador mais ou menos concreta. Barbara Goward é mais específica nessa relação entre narrador e autor. Para ela apenas o narrador externo se confunde com a ideia de autor: "O narrador externo de qualquer texto é seu autor implícito, que se dirige à audiência implícita, o narratário externo."5 (GOWARD, 1999, p. 09, tradução nossa).

À medida que a figura dionisíaca brinca com o jogo teatral, também joga com a figura do narrador. Como compreende Vernant (2014), Dioniso parece agir nos bastidores, assim também Vieira (2010, p. 18), no seu estudo sobre As Bacantes, observa que: "Além da perspectiva do espectador, incorporada pelos personagens das Bacantes, há a presença de outro olhar, o 'olímpico', que, distante da cena teatral, vislumbra a grandeza e a pequenez das ações humanas". Dioniso porta-se ao lado do dramaturgo, figura que Jong (2014) identifica com a do narrador, como se, com base em seu relato e de suas ações ao longo do enredo dramático, experimentasse os eventos externos que são narrados também pelas outras personagens, mesmo não tendo se retirado do palco. Seu conhecimento antecede a narrativa, tornando inclusive os narratologistas vítimas do jogo dionisíaco.

\footnotetext{
${ }^{5}$ No original: "the external narrator of any text is its implied author, addressing the implied audience, the external narratee."
}

https://periodicos.unifap.br/index.php/letras

Macapá, v. 8, n. 3, $2^{\circ}$ sem., 2018 
O primeiro a retornar ao relato do nascimento divino é o coro. Como seu deus de devoção, o coro é também estrangeiro e expõe sua própria origem no início de sua fala. O coro porta-se como se ele próprio fosse uma demonstração sensível aos não iniciados do poder de Dioniso, uma espécie de materialização da divindade, não sabe que o sacerdote que as lidera é o deus disfarçado. As bacantes deixam clara a dificuldade de cumprir o seu papel, mas também mostram o privilégio de sua posição (vv. 64-68) ${ }^{6}$. Elas aceitaram a influência báquica, comportam-se como se portassem um conhecimento que lhes fora partilhado pelo deus.

O conhecimento da realidade mítica e do contexto que encerra o enredo dramático advindo do deus, sua posição frente à pólis, colocam-nas ao lado de seu líder. Vernant (2014) afirma que uma das diferenças entre as lídias e as tebanas é que se identifica como ravia apenas o estado destas, sendo o coro denominado assim apenas uma única vez, quando, em desespero, por motivo da prisão de seu sacerdote.

O deus Baco representa a interseção das outras divindades e o que a nenhuma delas poderia ser atribuído. Tirésias, ao explicar a Penteu quem é o ser divino que ali chega, fá-lo a partir da relação do deus com outras divindades, com a aprovação do coro trágico: com Deméter, versão masculina do que ela representa (vv. 272-283)7 ; depois sobre sua filiação, Zeus e a ira de Hera, que o perseguiu, num novo relato do mito do nascimento de Dioniso (vv. 288-297) ${ }^{8}$; em seguida, a capacidade divinatória do deus, atividade comumente atribuída também a Febo Apolo (vv. 298-301)9; identifica a atividade dionisíaca com a de Ares (vv.302-305) ${ }^{10}$ e cita o comportamento bélico dos guerreiros, que mais à frente identificarse-á com o das mênades tebanas; o profeta menciona ainda Afrodite, o ambiente em que as mênades se encontram nada tem a ver com a deusa do amor e do desejo (vv. 314-318)11. A narrativa de Tirésias focaliza os eventos de maneira parecida com a de Baco e do coro. Ele é cego mas enxerga muito mais que os outros mortais, é capaz de enxergar a realidade de modo parecido com o divino.

O ambiente "selvagem" em que atua Dioniso retomando comportamentos e ritos religiosos anteriores à pólis da Grécia clássica, e, ao se considerar a afirmação de Vernant (2014) supracitada, uma das manifestações do elemento trágico em As Bacantes é a tensão que se

\footnotetext{
6 "Na terra asiática longe / deixei o sacro Tmolo e danço / por Crômio a doce dança / e a bem fatigante fadiga / na celebração de Báquio". (EURÍPIDES. Bacantes. Tradução de JAA Torrano. São Paulo: Hucitec, 1995, vv. 64-68).

7 "Esse Nume novato de quem tu escarneces / eu não poderia dizer quanta grandeza / terá na Grécia, porque dois, ó jovem, / princípios há entre os homens: Deméter Deusa / ou Terra, chama-a pelo nome que preferes, / ela com os sólidos nutre os mortais; / este veio equivalente, o filho de Sêmele: / úmido licor de uva inventou e apresentou / aos mortais, dos sofridos homens ele cessa / a dor quando se fartam do fluxo da uva, / dá sono e oblívio dos males cotidianos, / não há nenhum outro remédio das fadigas". (EURÍPIDES. Bacantes. Tradução de JAA Torrano. São Paulo: Hucitec, 1995, vv. 272-283).

8 "Quando o arrebatou do fogo fulminante, / Zeus levou ao Olimpo o filhote Deus, / Hera queria lança-lo fora do céu; / Zeus por sua vez tramou como Deus que é: / quebrou côdea do fulgor circunterrestre / e com ela fabricou entregando este Dioniso / refém da cólera de Hera. Co o tempo / mortais o dizem costurado na coxa de Zeus, / mudando nome; porque o Deus para a Deusa / Hera foi côdea-refém, compuseram o conto". (EURÍPIDES. Bacantes. Tradução de JAA Torrano. São Paulo: Hucitec, 1995, vv. 288-297).

9 "É adivinho este Nume, pois o báquico / e o louco têm muita arte de adivinhar: / quando o Deus vem pleno ao corpo / faz os enlouquecidos dizer o futuro". (EURÍPIDES. Bacantes. Tradução de JAA Torrano. São Paulo: Hucitec, 1995, vv. 298-301).

10 "E tem alguma participação em Ares / pois ao exército em armas e em ordem / o pavor atordoou antes de tocar a lança. / É a loucura, e isso provém de Dioniso". (EURÍPIDES. Bacantes. Tradução de JAA Torrano. São Paulo: Hucitec, 1995, vv. 302-305).

11 "Não Dioniso obrigará a ser sensatas / as mulheres em Afrodite mas por natureza / o ser sensato em tudo vigora sempre. / Isso se deve observar. E nos Baqueumas / presente a sensata não se corromperá” (EURÍPIDES. Bacantes. Tradução de JAA Torrano. São Paulo: Hucitec, 1995, vv. 314-318).
} 
instaura entre o deus da religião cívica, cultuado pelos espectadores da peça, e o deus que se apresenta na tragédia, de grandeza suficiente para que sua imagem não seja descrita pelos iniciados na religião, nem percebida pelos que não pertencem à religião de Dioniso.

Quando consideramos o conceito de focalização em Narratologia, percebemos que, em As Bacantes, o grau de conhecimento dos acontecimentos narrados, ou o posicionamento avaliativo desses acontecimentos se vinculam à crença do narrador na divindade dionisíaca. O termo focalização diz respeito ao quê e a como se percebem os eventos a serem narrados. É importante esclarecer que a focalização de uma narrativa vai além do que se vê, é um conceito que supera o de ponto de vista. Manfred Jahn (1996), em seu artigo Windows of focalization: Deconstructing and reconstructing a narratological concept, desenvolve uma discussão elucidativa sobre a formulação de um conceito com "uma abordagem interdisciplinar, integrativa e não dicotômica em relação à focalização"12 (JAHN, 1996, p. 241, tradução nossa). (EXCLUIR AQUI O APORTE TEÓRICO OU DESENVOLVÊ-LO)

\section{O PODER DE DIONISO: AS NARRATIVAS DOS MENSAGEIROS DE PENTEU}

As Bacantes apresenta três relatos de mensageiros. O primeiro, de um servo de Penteu que traz Dioniso, disfarçado de sacerdote, como prisioneiro, relata os prodígios realizados pelas mênades que se encontravam prisioneiras (vv. 434-450). A narrativa se desenvolve sob a perspectiva de como a vivenciou o narrador-personagem. A princípio, o estrangeiro era fera caçada, então, depois de se confrontar com ele, o servo the atribui a autoria da soltura das mulheres por meio de prodígios. Inferimos, nesse momento, que a narrativa do servo, incorporada ao enredo trágico, é marcada pelo que Jong (JONG, 2014, p. 68, tradução nossa) chama de "focalização hipotética embutida"13, isto é, os eventos até o momento da captura do estrangeiro são narrados numa perspectiva que se alinha à de Penteu, o narratário da história, mas não necessariamente compartilhada pelo narrador. Isso acontece provavelmente para que o servo não contrarie seu senhor e "prepare o terreno" para expor sua opinião sobre o acontecido e se desvencilhar de qualquer outra ação que indisponha o misterioso sacerdote. O servo não dispõe do conhecimento partilhado pelas bacantes lídias e por Tirésias, mas percebe que naquela situação estão envolvidas vontades que vão além da sua percepção. Por fim, ele avalia sua narrativa: muitas maravilhas chegam com este homem

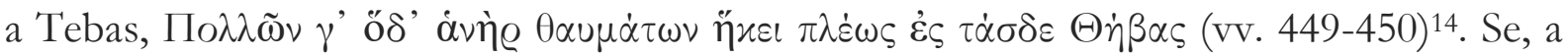
partir de sua captura, perdera a vontade de agir contra o estrangeiro, fizera-o sob os comandos de Penteu, agora se furta de qualquer outra ação, o estrangeiro não está mais sob seus cuidados.

No segundo relato, o mensageiro surge em cena após Dioniso/sacerdote se desvencilhar da prisão no palácio de Penteu e dos dois indivíduos novamente se encontrarem. Seu relato assume desde o início posicionamento parecido com o do servo ao final de sua narrativa. Para ele, um pastor que presenciou os atos das tebanas enlouquecidas, enquanto levava suas ovelhas à pastagem, elas são bacantes sagradas, veneráveis, $\beta \dot{\alpha} x \chi \alpha \varsigma$ $\pi 0 \tau \nu i \dot{\alpha} \delta \alpha \varsigma$ (v. 664), por isso, antes de relatar os acontecimentos, o mensageiro pede permissão ao rei,

\footnotetext{
${ }^{12}$ No original: "an interdisciplinar, integrative, and non-dichotomous approach towards focalization".

${ }^{13}$ No original: "hypothetical embedded focalization".

14 “Este homem chega a Tebas pleno de muitos mistérios". (Eu. Bacantes, vv.449-450, tradução nossa)
}

https://periodicos.unifap.br/index.php/letras Macapá, v. 8, n. 3, $2^{\circ}$ sem., 2018 
pois sabe que sua percepção pode desagradar o soberano (vv. 664-671) ${ }^{15}$. Ao contrário do jogo narrativo criado pelo servo, em que o narrador expõe os atos da maneira como os percebia ao experimentá-los, o mensageiro relata o acontecido de acordo com sua avaliação enquanto narrador, tendo já se desfeito inclusive da opinião de Penteu sobre a natureza divina dos atos das bacantes tebanas (vv. 680$688)^{16}$.

O lugar em que se situam as tebanas é descrito como um ambiente em que o divino e o mortal estão em confluência, expressa pela união entre elas e os animais, domésticos ou selvagens. Elas se alimentam de leite, vinho e mel retirados da terra, das rochas e de seus tirsos, são seres divinos. As tebanas estão possuídas pelo furor báquico e agem em harmonia com o deus, tendo a disposição os poderes de Dioniso, conforme o mensageiro deixa entrever no seu longo discurso.

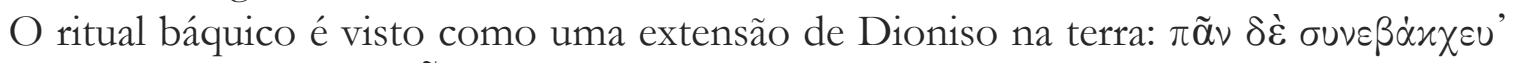

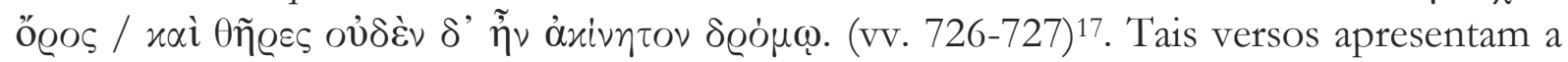
experiência de quem esteve diante de um fenômeno divino. Trata-se de um evento que apenas se alcança através da narrativa, enriquecida pela criatividade de seu narrador, pois vai além da percepção sensorial, e por meio da focalização percebemos que o relato menciona o acontecido sem a necessidade de abarcar toda a sua realidade. Sobre esse evento,

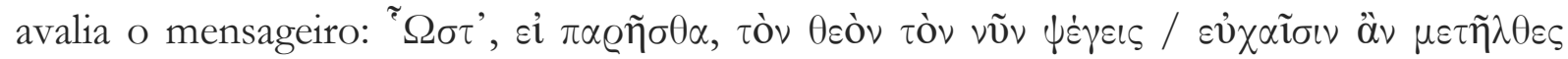
$\varepsilon \dot{\imath} \sigma \iota \delta \grave{\omega} \nu \tau \dot{\alpha} \delta \varepsilon$. (vv. 712-713)

O pastor é convencido, junto com seus companheiros, por um "vadio de boa lábia" a capturar a mãe do rei, a fim de ganhar sua graça. Dá-se o confronto, e a harmonia entre bacantes e divindade, que era expressa pela harmonia das mulheres com a vida selvagem, agora se apresentará pelo poderio bélico, pela força e pelo comportamento de guerreiras ou de animais selvagens em defesa de seu bando. Ao sofrerem o ataque dos pastores, as mulheres enchiam-se de força e devastavam o que com elas cruzava em uma verdadeira onda de fúria divina. A situação torna-se tensa quando elas descem os montes e invadem a pólis. Misturam-se o selvagem, o feminino e a ordem divina com o masculino, o civilizado e a ordem mortal. A oposição entre Penteu e o sacerdote agora é vista em um espaço em que a ordem divina é representada pela ordem mortal. As mênades dilaceraram rebanhos com as mãos nuas. Vacas e touros tornaram-se carne, chifres e sangue espalhados pelo pasto. Os homens pegam armas, mas nada podem fazer contra aquelas guerreiras selvagens, que não precisavam se desviar dos dardos masculinos, inofensivos contra elas, protegidas pela divindade que agora se prova diferente de Afrodite. As mulheres não estão entregues a rituais sensuais ou de fertilidade, o poder dionisíaco ultrapassa o comportamento lascivo e os momentos idílicos de contato com a natureza. O deus Baco desfaz e refaz a realidade.

\footnotetext{
15 'Vi Bacas veneráveis que desta terra / aguilhoadas dispararam desnudo pé. / Venho informar a ti e à cidade, ó rei, / que fazem proezas maiores que milagres. / Quero ouvir-te se com a palavra toda / informo aquilo lá ou se recolho a fala, / pois temo a rapidez de teu espírito, ó rei, / e o ânimo súbito e a majestade a mais." (EURÍPIDES. Bacantes. Tradução de JAA Torrano. São Paulo: Hucitec, 1995, vv. 664-671).

16 "Vejo três tíasos de femininos coros: / Autônoe regia o primeiro, tua mãe Agave / o segundo e Ino regia o terceiro tíaso. / Todas dormiam, derramados os corpos: / umas apóiam as costas em ramo de abeto, / outras em folhas de carvalho abandonam / a cabeça no chão, casadas e não, como dizes, / embriagadas de vinho e sons de flauta / enamoradas a caçar Afrodite na floresta”. (EURÍPIDES. Bacantes. Tradução de JAA Torrano. São Paulo: Hucitec, 1995, vv. 680-688).

17 “Toda a montanha e as feras se embriagaram de alegria, e nada estava imóvel na corrida". (Eu., Bacantes, vv. 726-727, tradução nossa)

18 "Logo, se presente, o deus que agora censuras / com preces, tu retornarias, caso visses isso. (Eu., Bacantes, vv. $712-$ 713 , tradução nossa)
} 
Desse embate saem as mulheres vitoriosas e os homens convencidos da soberania da divindade que as defende. Assim, resta ao mensageiro, enquanto narrador, formular a sua moral, enquanto cidadão tebano intentar convencer o seu rei de que o deus já está instalado em Tebas e que o melhor a fazer é aceitá-lo e cultuá-lo, pois, sem vinho, não haverá também os prazeres permitidos aos homens (vv. 769-774). ${ }^{19}$

A narrativa, porém, não convence o rei tebano, que da mensagem só apreende o vexame dos homens diante do bando feminino e já organiza uma revanche. Frente às novas tentativas de Dioniso-sacerdote de convencê-lo de que o que resta é prestar sacrifício

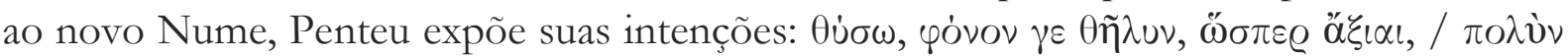
$\tau \alpha \varrho \dot{\alpha} \xi \alpha \varsigma \dot{\varepsilon} \nu$ Kı $\theta \alpha \varrho \tilde{\omega} v o \varsigma \pi \tau v \chi \alpha \tilde{l} \varsigma$. (vv. 796-797)20 efetuar, se necessário, uma carnificina de fêmeas nos montes do Citéron.

Esse é o momento crucial do enredo dramático. Mesmo com todas as indicações, Penteu não se dobra e mantém sua oposição ao imortal. A vaidade o leva a concluir sua $v ̋$ oıs. A Dioniso, sem argumentos que possam dissuadi-lo, cabe agora castigá-lo. Antes de encaminhá-lo à morte, o deus formula situação que ridiculariza a imagem do rei: leva-o, enfeiti-

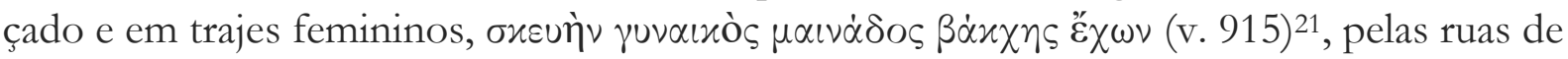
Tebas rumo ao monte Citéron. Acompanha a ação o canto coral.

A terceira narrativa é feita por outro servo, é acompanhada de sua lamentação por ter presenciado a morte de seu senhor e tem como narratário o coro. Enquanto servo do pa-

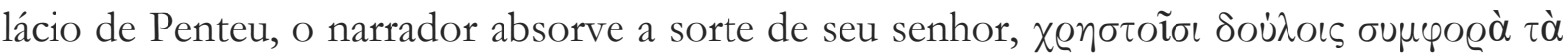

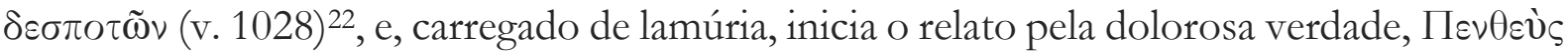

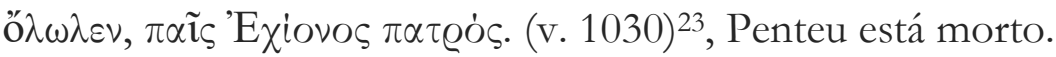

Após deixarem a pólis e rumarem para dentro do ambiente selvagem, o servo, seu senhor e o forasteiro alcançam o Citéron e as loucas em seus ritos báquicos. Penteu está enfeitiçado, possuído pelo desejo de vislumbrar as mênades, mas está cego. Seu estado também é obra dionisíaca. Enquanto saíam de Tebas, ainda em cena, Penteu e o forasteiro conversam numa língua, que nos faz pensar ser impossível uma conciliação entre as instancias divina e humana.

Como a narrativa do primeiro mensageiro, o segundo relato também apresenta uma "focalização narrativa interna" 24 (JONG, 2014, p. 65, tradução nossa). Isto é, o narrador-personagem testemunhou seu relato, nesse caso, numa perspectiva próxima da do protagonista da narrativa, e incorpora a sua narração, a própria avaliação do acontecido, resultante de uma reflexão que se deu no momento do acontecimento e nos momentos posteriores à ação e anteriores à narração. Por isso, a narrativa é precedida do veredito "Penteu está morto, o filho de Equíon."; e assim, antes de Dioniso oferecer o rei tebano às mênades, o narrador se refere a Penteu pelo adjetivo $\tau \lambda \dot{\eta} \mu \omega \nu$ (v.1058), vocábulo que tanto pode significar "paciente, perseverante", como "coitado, sofredor".

A partir da insistência de Penteu, o forasteiro começa a revelar-se como divindade. Seu

\footnotetext{
19 “A este Nume então quem seja, ó senhor, / recebe-o neste país. Que ele é magnífico, / ainda isto o proclama, segundo eu ouvi: / deu a dolorífiga videira aos mortais. / Vinho não mais havendo, não há Cupris / nem têm os mortais nenhum outro prazer". (EURÍPIDES. Bacantes. Tradução de JAA Torrano. São Paulo: Hucitec, 1995, vv. 769-774).

20 "Sacrificarei, sim, sangue feminino, visto que elas são dignas, / fazendo grande confusão no cume do Citaron" (Eu., Bacantes, vv. 796-797, tradução nossa)

21 "Em trajes de uma mulher bacante louca". (Eu., Bacantes, vv. 915, tradução nossa)

22 "Os prestativos servos têm a fortuna de seus senhores". (Eu., Bacantes, v. 1028, tradução nossa)

23 "Penteu está morto, o filho de Equíon". (Eu., Bacantes, v. 1030, tradução nossa)

${ }^{24}$ No original: "narrating internal focalization".
} 
primeiro prodígio é possibilitado por força superior: ele traz a ponta de uma árvore conífera ao chão para que Penteu se acomode e, ao retorno do galho, possa ver confortavelmente e com clareza o movimento das loucas.

A grandeza do ato se apresenta de três maneiras. Primeiramente, é concebido

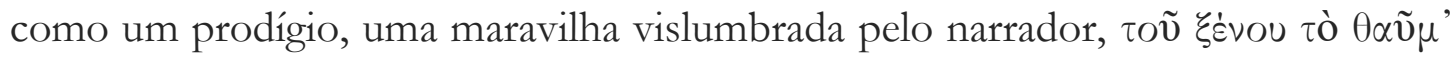
ó@ஸ̃ (v. 1063)25. Em seguida, a repetição do ato de puxar o galho: o forasteiro des-

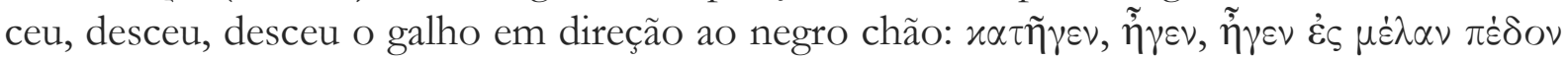

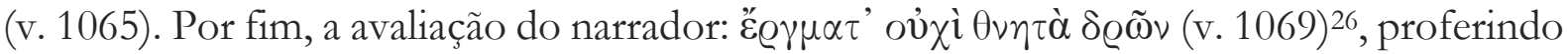
que ele realizou um proeza de que só um imortal é capaz.

Depois de Penteu ser visto pelas mênades, o forasteiro some e o ambiente se transforma. Uma voz, que o próprio narrador agora atribui a Dioniso, atiça as loucas e as ações que se passam daqui por diante na narrativa, novamente se mesclam entre atos aterrorizantes e inacessíveis ao drama.

Dioniso deixa de lado os subterfúgios e mostra sua verdadeira intenção: Penteu aprenderá da pior forma que não se deve ir contra a vontade divina. A cegueira da razão, que se manifestou nos últimos momentos pela cegueira da visão (Dioniso dissera ao conduzi-lo que ele via apenas o que o deus queria), se desfaz quando o herói trágico se vê cercado pelas mênades, lideradas por sua mãe e por suas tias, no abeto que se faz seu castelo, ह̣̌@ı $\tau \tau o v$ (v. 1097) lançado para longe. A narrativa a essa altura também ganha tonalidade bélica. As guerreiras invadem a torre e depõem seu rei.

O ritmo narrativo torna-se lento, as cenas são descritas uma a uma, em uma sequência de frames que recriam a angústia de Penteu, desde o ataque bacante, até a compreensão de

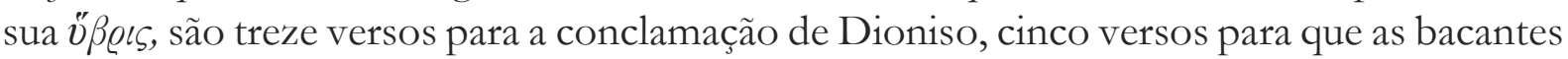
percorram o caminho do ponto inicial até o lugar onde se encontra Penteu, dez versos até que, após seguidas tentativas de agarrá-lo, resolvam arrancar a árvore em que ele se encontra, sete versos até que a árvore seja desenraizada, e, por fim, a queda, descrita lentamente em três versos, representa a ruína de Penteu, que toma consciência de seu desastre: xaxoṽ

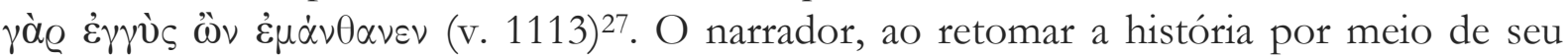
relato, preenche as lacunas resultantes da sua limitação sensorial por meio de inferência, $\dot{\omega} \varsigma$

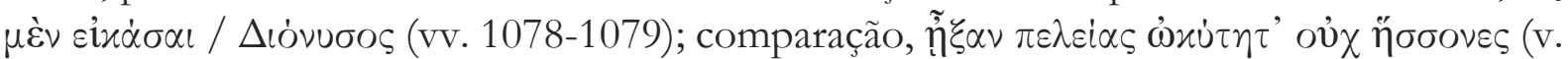

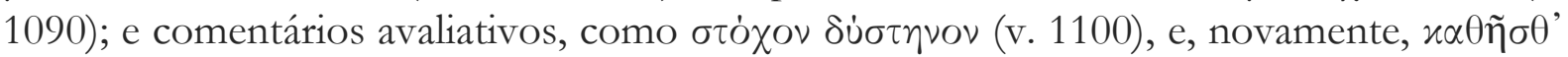
ò $\tau \lambda \dot{\eta} \mu \omega \nu,($ v. 1102) 28 .

No chão, já ciente de seu castigo, Penteu é confrontado pela mãe enlouquecida e apela por sua vida, mas é inútil. A mãe não ouve o filho, está possuída por Baco, é $\varkappa$ Baxxiov

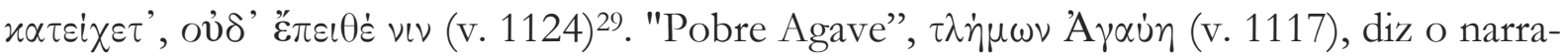
dor, ataca-o como a uma presa. Enquanto tentava derrubá-lo do abeto, a mãe gritava a suas

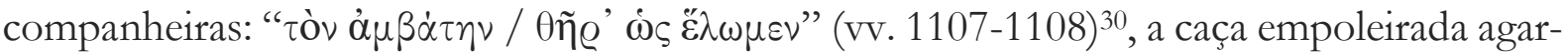
remos! Para ela, Penteu não passa de uma caça lamuriosa. Arranca-lhe o braço esquerdo e as companheiras dão continuidade à dilaceração da fera, enquanto as bacantes festejam a

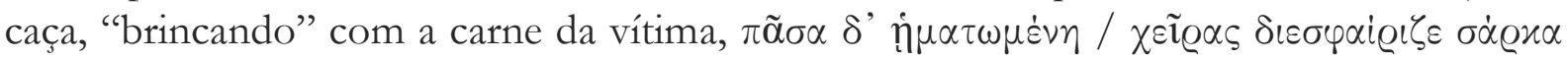

\footnotetext{
25 "Vejo o espanto do estrangeiro" (Eu., Bacantes, v. 1063, tradução nossa)

26 "Fazendo proezas não de mortais". (Eu., Bacantes, v. 1069, tradução nossa)

27 "Pois, perto da ruína, aprende". (Eu., Bacantes, v. 1113, tradução nossa)

28 “Como parece, Dioniso...”; “pularam não menos rápidas que pombas...”; “desgraçado alvo...”; “sentava-se o coitado sofredor...” (Eu., Bacantes, vv. 1078-1079; v. 1090; v. 1100; v. 1102, respectivamente, tradução nossa)

29 "Possuída por Baco, não conseguia persuadi-la", (Eu., Bacantes, v. 124, tradução nossa)

30 “... o tronco, para que capturemos a fera...”, (Eu., Bacantes, vv. 1107-1108, tradução nossa)
} 


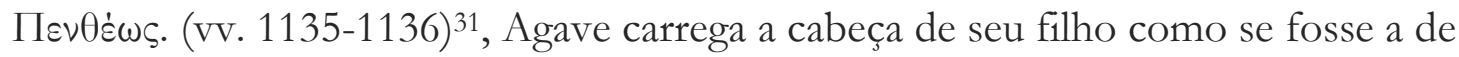
um filhote de leão.

Este último trecho narrativo se valoriza pelas prolepsis anteriores de Dionisosacerdote, que mudam de tom quando surgem em diálogo com o coro e ao travar discussão com o rei de Tebas. Por meio da narrativa, ganham novo significado falas como a referência ao nome de Penteu, feita por Dioniso, e anteriormente mencionada pelo velho Tirésias. Para o adivinho, não é preciso usar de suas previsões para imaginar o que vai acontecer ao jovem rei, "o nome de Penteu anuncia o seu destino: Penthéus/pénthos, 'dor', 'luto”' (TORRANO, In. EURÍPIDES, 1995, p. 24)

\section{CONSIDERAÇÕES FINAIS}

O drama euripidiano joga com os níveis de conhecimento, que vão desde o saber terreno, próprio dos mortais, ao conhecimento divino, de qual os deuses se apropriam. Essa discussão foi iniciada em nosso trabalho quando comparamos os níveis de conhecimento do mundo divino com a focalização assumida por cada uma das narrativas analisadas acima, nas quais, se opusermos Penteu a Dioniso, situamos o nível de conhecimento dos narradores entre os dois, mais proximamente a um ou a outro, de acordo com a focalização de sua narrativa, ou com seus atos ao longo do enredo dramático. Nesse caso, enquanto os servos estão próximos da cegueira de Penteu, posto que, apesar de verificarem a possibilidade da veracidade do poder divino de Dioniso, estão limitados pela sua condição de seres mortais; ao coro de bacantes lídias e ao profeta Tirésias, apesar de mortais, é permitido vislumbrar a realidade divina, sem se afastarem ou negarem a condição mortal, e, por isso, situam-se mais próximos da divindade, permanecendo incólumes à ira dionisíaca.

As narrativas incorporadas ao drama, mesmo que aparentem despretensiosas quanto a sua estrutura pela pouca extensão ou por se tratar de narrativas incorporadas a um enredo maior, o que esperamos ter mostrado tratar-se de uma concepção equivocada, conferem a noção de completude do enredo dramático, ao mesmo tempo em que demonstram a grandeza do poder de Dioniso. Trazem ao palco os atos divinos praticados nos bastidores e demonstram, seja pela temática, seja pela incorporação de ações à fábula dramatizada, a pequenez da vontade humana frente ao complicado movimento universal expresso pela vontade dos deuses.

Em As Bacantes, percebemos como Eurípides, através da ironia, da comicidade e da loucura conferida pelo estado de furor dos que praticam o culto báquico, três elementos constitutivos da identidade dionisíaca no panteão grego, expõe a sujeição humana aos caprichos dos deuses.

\section{REFERÊNCIAS}

DODDS, E. R. Os gregos e o irracional. Tradução de Paulo Domenech Oneto. São Paulo: Escuta, 2002.

EURÍPIDES. As Bacantes. In: VIEIRA, Trajano. As bacantes de Eurípides. São Paulo: Perspectiva, 2010.

GOWARD, Barbara. Telling Tragedy: Narrative Technique in Aeschylus, Sophocles and Euripides. London: Duckworth, 2004.

31 “E toda ensanguentada nas mãos, jogava bola com a cabeça de Penteu”, (Eu., Bacantes, vv. 1135-1136, tradução nossa) 
ISIDRO PEREIRA, S. J. Dicionário grego-português e português-grego. Braga: Livraria Apostolado da Imprensa, 1990.

JAHN, Manfred. Windows of focalization: Deconstructing and reconstructing a narratological concept. In: Style, v. 30, n. 2, p. 241, 1996.

JONG, Irene J. F. de. Narratology and Classics: a pratical guide. Oxford: Oxford Press, 2014.

TORRANO, Jaa. O mito de Dioniso. In: EURÍPIDES. Bacas: o mito de Dioniso = Bakxai. Estudo e tradução de Jaa Torrano. São Paulo: Hucitec, 1995.

VERNANT, Jean-Pierre. Mito e religião na Grécia antiga. Tradução de Joana Angélica D’Avila Melo. São Paulo: WMF Martins Fontes, 2006.

. O Dioniso mascarado das Bacantes de Euripides. In: VERNANT, Jean Pierre; VIDAL-NAQUET, Pierre. Mito e tragédia na Grécia Antiga. São Paulo: Perspectiva, 2014 